Despite competing demands, modern organizations should not forget that learning is the best way to meet the challenges of the time. Learning charters demonstrate commitment: they are a touchstone against

which provision and practice can be tested and a waymark with which to guide, monitor, and evaluate progress. It is difficult

to argue that what

learning charters advocate is not worth striving for.

\title{
Drawing Learning Charters
}

\section{By Olivier Serrat}

\section{Communicating for Change}

Often, strategic reversals in organizational change are failures of execution. Poor communications explain much. That is because the real power of the vision that underpins change can only be unleashed if institutional commitment is verbalized to frame a desirable future; share core beliefs, common values, and understandings; and help motivate and coordinate the actions that drive transformation.

To spark action, credible, focused, jargon-free, ontime, liberal, face-to-face, and two-way communication ${ }^{1}$ in the right context is necessary. Effective visions cannot

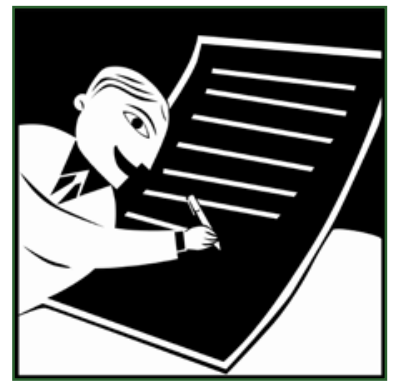
be imposed on people: they must be set in motion by way of persuasion. Progressively then, communication for change (i) raises awareness and informs stakeholders of vision, progress, and outcomes; (ii) edifies stakeholders regarding their active involvement in the change process and imparts skills, knowledge, and appreciation; and (iii) generates buyin and a sense of excitement about the tranformation. ${ }^{2}$ Personnel who communicate well incorporate each day, at every conceivable opportunity, messages that update, educate, and commit. They preach a vision through conversation and storytelling. They continually reaffirm it. The best visions call on the past, relate to the present, and link to the future.

\section{Drawing Learning Charters}

A charter is a written instrument given as evidence of agreement. ${ }^{3}$ It can also be a document setting forth the aims and principles of a united group to inform stakeholders in

The pillars of effective communication are (i) simplicity; (ii) metaphor, analogy, and illustration; (iii) multiple forums; (iv) repetition; (v) leadership by example; (vi) explanation of apparent inconsistencies; and (vii) give-andtake.

Depending on the organization, audiences, and the nature of the change, these must be aligned along a commitment curve of contact, awareness, understanding, positive perception, adoption, institutionalization, and internalization

In numerous instances, that can be a document issued by a sovereign, legislature, or other authority to create a public or private corporation, e.g., a city, college, or bank, and define its privileges and purposes. 
an endeavor and serve as a reference of authority for the future. A clear, concise statement of the direction of an organization that outlines purposes and results is a useful tool with which to stimulate enthusiasm.

For example, the Learning Declaration Group ${ }^{4}$ has promoted learning and development for many years. The 13 signatories $^{5}$ to its Declaration on Learning, people who have researched and written extensively about effective learning, ${ }^{6}$ have isolated the benefits for society, organizations, and individuals. The declaration spells out what these are and invites responses from policy makers; leaders in organizations; teachers, trainers, and

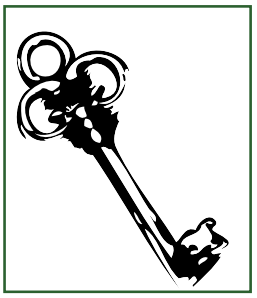
developers; and individual learners. The notable tenets of the declaration include:

- Learning reinforces the informed, conscious, and discriminating choices that underpin democracy.

- Learning is the only source of sustainable development.

- Learning to learn is the most fundamental learning of all.

- Learning is the key to developing your identity and your potential.

- Society, and the communities of which it is comprised, survives, adapts, and thrives through developing and sharing learning.

- Regular and rigorous use of learning processes increases everyone's capacity to contribute to the success

He that gives good advice, builds with one hand; he that gives good counsel and example, builds with both; but he that gives good admonition and bad example, builds with one hand and pulls down with the other.

-Francis Bacon of organizations by challenging, reshaping, and meeting its goals.

- Learning expands the horizons of who we are and what we can become.

Since the first version of the declaration was launched in 1998, the group has received reactions ranging from "It's not very radical" to 'It's too radical for us to implement." More critically, others have decried the communication mode of the declaration - which mixes principles, analyses, and plans of action somewhat indigestibly — or demonstrated its dominant discourses and assumptions. Yet, its avowed intention is only to promote dialogue on learning in organizations, and its originality lies in the fact that very few organizations practice what is suggested in the paper. It poses fascinating questions: specifically, how can policy makers; leaders in organizations; teachers, trainers, and developers; and individual learners maximize the learning ability of people by encouraging and supporting individual and collective learning that enables society, organizations, and individuals to change and adapt more effectively?

\section{Learning for Change in ADB}

In 2009, a publication ${ }^{7}$ of the Asian Development Bank examined what that organization might say, to what purposes and results, and through what commitments to corporate action, if it were to make a statement of intent on learning for change in ADB. If its staff members were to pledge themselves to individual actions, what might these be? The learning charter that the document champions is not prescriptive, nor is it exhaustive. But it is assuredly specific, measurable, achievable, realistic, and timely.

\footnotetext{
4 See lan Cunningham. 2006. A Declaration on Learning: How Do You Respond? Development and Learning in Organizations. Vol. 20, No. 6: $18-23$.

5 They are Margaret Attwood, Tom Boydell, John Burgoyne, David Clutterbuck, lan Cunningham, Bob Garratt, Peter Honey, Andrew Mayo, David Megginson, Alan Mumford, Michael Pearn, Mike Pedler, and Robin Wood.

The characteristics of effective learning are reflectiveness, resourcefulness, reciprocity, and resilience.

7 ADB. 2009. Learning for Change in ADB. Manila. Available: www.adb.org/documents/books/learning-for-change/default.asp
} 
Figure: A Learning Charter for ADB

Statement of Intent

- $\mathrm{ADB}$ embraces the concepts of the learning organization to work better with its developing member countries and cultivate the talent of its staff members.

Purposes and Results

- To take concrete actions to transform $\mathrm{ADB}$ into a learning organization in its policies, strategies, programs, and projects, as well as the business processes and partnerships associated with these, to meet the challenges of the time.

- To support lifelong learning and development by staff members to ensure that ADB is able to attract, retain, and develop the talent it needs in support of its mission.

Commitments to Corporate Action

- Hold a regular caucus on learning (such as a forum on "Learning in Action").

- Clarify, simplify, and drive governance for human resources management, including learning and development.

- Make clear the roles and responsibilities for learning and development so that there is clear accountability for results.

- Develop learning and development plans in every department and office, and track and evaluate results.

- Establish a minimum annual commitment of funds or time for learning for employees.

Commitments to Individual Action

- Be open to different ideas and ways of doing things.

- Build (and model) an environment where discussion, debate, and questioning are encouraged.

- Look out for good practices and capture and share them as appropriate.

- Investigate and master tools, methods, and approaches that might enrich team discussions.

- Seek regular inputs from clients, and benchmark the services provided against the best in ADB and comparable aid agencies.

- Hold regular team meetings to examine what could be done differently, capture lessons learned, and share lessons with others.

- Participate in communities of practice and other value networks, and encourage staff members to do the same.

- Volunteer to coach and mentor younger or new staff members, and build requisite skills continuously.

- Prepare an individual learning and development plan that incorporates my needs and demonstrates what I will do to support those of others.

- Work with my teams to develop team learning and development plans.

- Cooperate with staff members under my supervision to develop individual learning and development plans that reflect a balance of organizational and personal learning and development needs.

- Provide time and resources necessary to live up to the learning and development needs determined and agreed upon.

- Monitor and evaluate the learning and development activities of staff members under my supervision.

- Take care that I have a diversity of talents, skills, and perspectives represented on teams.

- Ensure that staff members in my unit have the chance to share learning and development experiences with others.

- Resist the temptation to divert learning and development funds to other uses or to use operational requirements as an excuse to delay learning.

Source: ADB. 2009. Learning for Change in ADB. Manila. Available: www.adb.org/documents/books/learning-for-change/default.asp

ADB offers other recent examples of statements on learning. On 31 July 2009, Haruhiko Kuroda-ADB President and concurrent Chairperson of ADB's Board of Directors-approved Enhancing Knowledge Management Under Strategy $2020^{8}$ to advance the knowledge management agenda under Strategy 2020: The Long-Term Strategic Framework of the Asian Development Bank (2008-2020). ${ }^{9}$ Four pillars will support the plan of action: (i) sharpening the knowledge focus in all ADB operations, (ii) promoting and empowering communities of practice for knowledge capture and sharing, (iii) strengthening external knowledge partnerships to develop and disseminate knowledge, and (iv) scaling up staff development programs to improve technical skills and manage knowledge. In relation to the second, ADB's Knowledge Management Center proposed for adoption by ADB's communities of practice a dynamic, interactive, and organic framework that articulates the need to ask, learn, and share at individual, team, and community levels. From a knowledge sharing and learning perspective, translating the framework into inputs, activities, and outputs for key outcomes will help maintain focus on the things that matter to communities of practice and serve the needs and aspirations of their members.

8 See ADB. 2009. Enhancing Knowledge Management Strategies. Manila. Available: www.adb.org/documents/information/knowledgesolutions/enhancing-knowledge-management-strategies.pdf

9 ADB. 2008. Strategy 2020: The Long-Term Strategic Framework of the Asian Development Bank (2008-2020). Manila. Available: www.adb. org/documents/policies/strategy2020/strategy2020.pdf 


\section{Knowledge
Solutions}

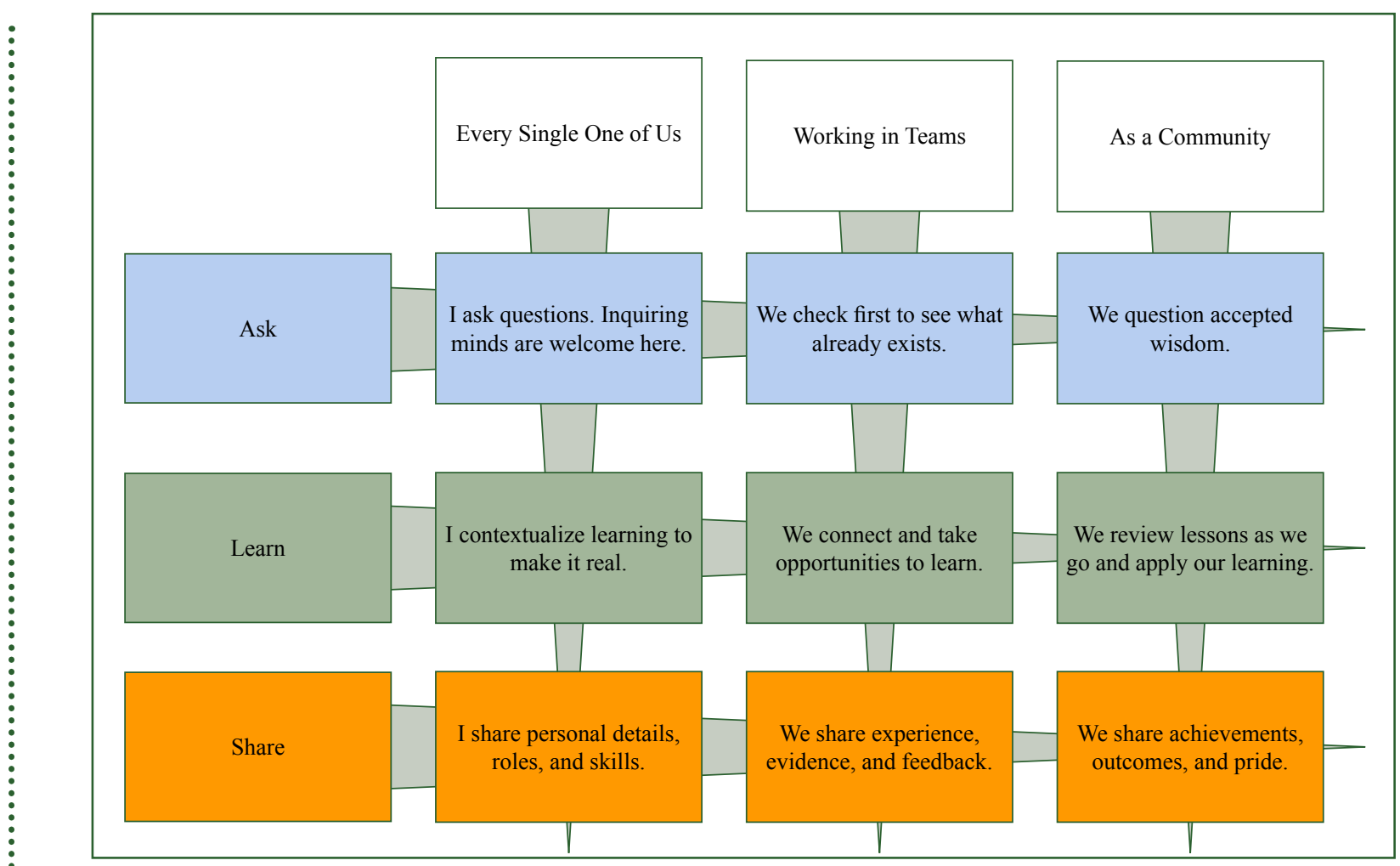

Source: ADB. 2009. Cultivating the Communities of Practice Hosted by ADB. Manila. Available: www.adb.org/documents/presentations/ knowledge-management-and-learning/cultivating-communities-of-practice.pdf

\section{Further Reading}

ADB. 2009. Learning for Change in ADB. Manila. Available: www.adb.org/documents/books/learning-forchange/default.asp

\section{For further information}

Contact Olivier Serrat, Head of the Knowledge Management Center, Regional and Sustainable Development Department, Asian Development Bank (oserrat@adb.org). 
Asian Development Bank

$A D B$ 's vision is an Asia and Pacific region free of poverty. Its mission is to help its developing member countries reduce poverty and improve the quality of life of their people. Despite the region's many successes, it remains home to two thirds of the world's poor: 1.8 billion people who live on less than $\$ 2$ a day, with 903 million struggling on less than $\$ 1.25$ a day. ADB is committed to reducing poverty through inclusive economic growth, environmentally sustainable growth, and regional integration.

Based in Manila, ADB is owned by 67 members, including 48 from the region. Its main instruments for helping its developing member countries are policy dialogue, loans, equity investments, guarantees, grants, and technical assistance.

Knowledge Solutions are handy, quick reference guides to tools, methods, and approaches that propel development forward and enhance its effects. They are offered as resources to ADB staff. They may also appeal to the development community and people having interest in knowledge and learning.

The views expressed in this publication are those of the author(s) and do not necessarily reflect the views and policies of the Asian Development Bank (ADB) or its Board of Governors or the governments they represent $A D B$ encourages printing or copying information exclusively for personal and noncommercial use with proper acknowledgment of ADB. Users are restricted from reselling, redistributing, or creating derivative works for commercial purposes without the express, written consent of ADB.

Asian Development Bank

6 ADB Avenue, Mandaluyong City

1550 Metro Manila, Philippines

Tel +6326324444

Fax +6326362444

knowledge@adb.org

www.adb.org/knowledgesolutions 